\title{
Changes in the Maternal Hypothalamic-Pituitary- Adrenal Axis in Pregnancy and Postpartum: Influences on Maternal and Fetal Outcomes
}

\author{
Leanne Duthie Rebecca M. Reynolds \\ Endocrinology Unit, University/British Heart Foundation Centre for Cardiovascular Science, \\ Queen's Medical Research Institute, University of Edinburgh, Edinburgh, UK
}

\section{Key Words}

HPA axis · Pregnancy $\cdot$ Mood $\cdot$ Programming

\begin{abstract}
Overexposure of the developing fetus to glucocorticoids is hypothesised to be one of the key mechanisms linking early life development with later life disease. The maternal hypothalamic-pituitary-adrenal (HPA) axis undergoes dramatic changes during pregnancy and postpartum. Although cortisol levels rise threefold by the third trimester, the fetus is partially protected from high cortisol by activity of the enzyme 11ß-hydroxysteroid dehydrogenase type 2 (HSD11B2). Maternal HPA axis activity and activity of HSD11B2 may be modified by maternal stress and disease allowing greater transfer of glucocorticoids from mother to fetus. Here we review emerging data from human studies linking dysregulation of the maternal HPA axis to outcomes in both the mother and her offspring. For the offspring, greater glucocorticoid exposure is associated with lower birth weight and shorter gestation at delivery. In addition, evidence supports longer term consequences for the offspring including re-setting of the HPA axis and susceptibility to neurodevelopmental problems and cardiometabolic disease. For the mother, the changes in the HPA axis, particularly in the postpartum period, may increase vulnerability to mood disturbances. Fur-
\end{abstract}

ther understanding of the changes in the HPA axis during pregnancy and the impact of these changes may ultimately allow early identification of those most at risk of future disease.

Copyright $\odot 2013$ S. Karger AG, Basel

\section{Introduction}

There is increasing epidemiological evidence supporting the hypothesis that adult vulnerability to disease is 'programmed' in fetal life, and therefore shaped by the intrauterine environment as originally postulated in the Barker hypothesis [1-7]. Overexposure of the developing fetus to excess glucocorticoids is thought to be one of the key mechanisms underlying early life programming of disease $[8,9]$. It is proposed that dysregulation of the maternal hypothalamic-pituitary-adrenal (HPA) axis determines fetal exposure to stress hormones influencing development and birth outcomes and also programming the fetal HPA axis, thus determining responses to stress and susceptibility to physical and mental illness in later life. This hypothesis is supported by animal studies showing that maternal glucocorticoid overexposure leads to adverse outcomes in the offspring including metabolic disorders and behavioural/anxiety phenotypes [10-19].

\section{KARGER}

E-Mail karger@karger.com

www.karger.com/nen (c) 2013 S. Karger AG, Basel

0028-3835/13/0982-0106\$38.00/0
Rebecca Reynolds

Endocrinology Unit, University/BHF Centre for Cardiovascular Science

Queen's Medical Research Institute, 47 Little France Crescent

Edinburgh EH16 4TJ (UK)

E-Mail R.Reynolds@ed.ac.uk 


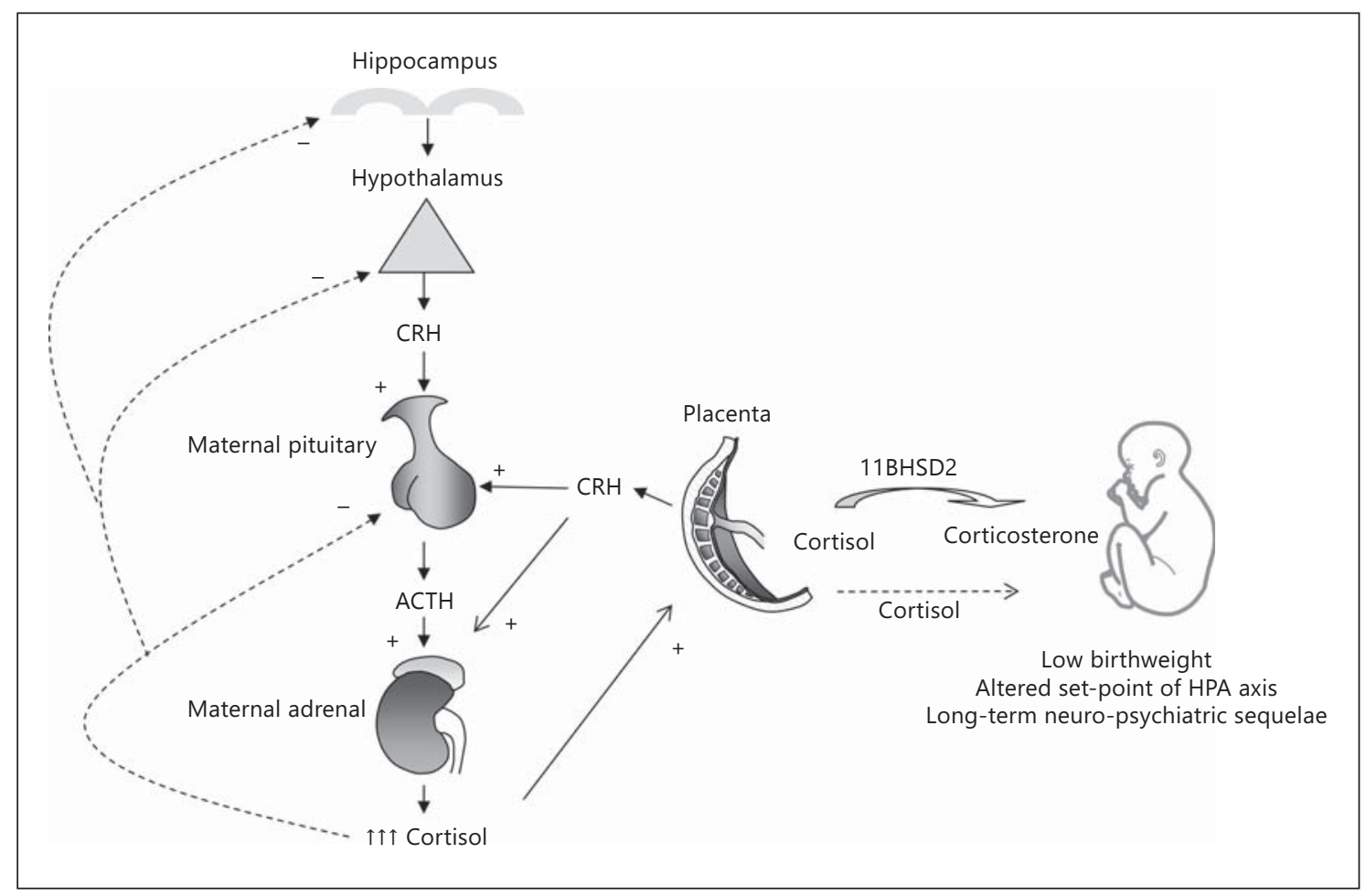

Fig. 1. HPA axis in pregnancy. Secretion of cortisol from the adrenal glands is regulated by central negative feedback. In pregnancy, placental CRH stimulates both the maternal pituitary and adrenal, leading to increased cortisol production. Rising cortisol can also stimulate further placental CRH production. Passage of cortisol through the placenta is partially inhibited by placental HSD2. Glucocorticoid overexposure has adverse sequelae for the developing fetus.

In humans, fetal glucocorticoid overexposure has been linked to development of cardiometabolic disease [20,21] and there is a growing interest in the role of stress and glucocorticoid excess on offspring neurodevelopment and subsequent vulnerability to mental illness [22-34]. This is important as childhood neurodevelopmental problems and mental health disorders are major public health issues, so understanding the origins of these disorders may ultimately guide preventative strategies. In this mini-review we examine emerging evidence from human studies linking changes in the maternal HPA axis during pregnancy and postpartum with maternal and fetal outcomes with particular focus on the potential role of $11 \beta$-hydroxysteroid dehydrogenase type 2 (HSD11B2).

\section{The Maternal HPA Axis}

The HPA axis mediates the stress response of glucocorticoids. Corticotrophin-releasing hormone $(\mathrm{CRH})$ is released from the paraventricular nucleus in the hypothala- mus in response to stressors and stimulates the release of adrenocorticotrophin hormone (ACTH) from the pituitary gland. In turn, ACTH stimulates the adrenal cortex to secrete cortisol into the bloodstream. Cortisol feeds back to glucocorticoid and mineralocorticoid receptors in the pituitary and hypothalamus to regulate its own secretion. During pregnancy, the regulation of the maternal HPA axis undergoes dramatic changes (fig. 1). Circulating cortisol levels rise markedly to around threefold nonpregnant levels by the third trimester [35]. This rise in cortisol is partly due to oestrogen stimulation of corticosteroid-binding globulin with a rise in free (or bioavailable) cortisol levels $[36,37]$. In addition, the placenta secretes large quantities of CRH into the maternal bloodstream during the second and third trimesters of pregnancy [38-40]. Placental CRH stimulates the maternal pituitary gland, thus further increasing both ACTH and consequently cortisol levels. In turn, maternal cortisol stimulates placental CRH synthesis creating a positive feed-forward drive with resultant higher cortisol levels $[41,42]$. Despite the increasing circulating levels of corti- 
sol, the diurnal secretion of cortisol is maintained throughout pregnancy [43]. However, as pregnancy progresses, the increased circulating cortisol downregulates hypothalamic production of CRH and thus the responsiveness of the HPA axis to both physiological and psychological stress is attenuated during late pregnancy [44-46].

The fetus is protected from high levels of maternal glucocorticoids by the action of the placental enzyme HSD11B2. This enzyme converts active glucocorticoids (cortisol) into inactive glucocorticoids (cortisone), thus protecting the fetus from excessive glucocorticoid exposure [47-49]. Although a substantial proportion of cortisol $(80-90 \%)$ is metabolised by the placenta during gestation, excess cortisol may reach the fetus [50] and the 'barrier' can be further weakened by maternal anxiety [51-55], infection [56] and inflammation [57] allowing increased transfer of glucocorticoids from mother to fetus. As maternal cortisol levels are so much higher than fetal levels, even modest variations in placental HSD11B2 can significantly alter fetal glucocorticoid exposure. In human pregnancy where it is difficult to measure HSD11B2 activity or fetal glucocorticoid exposure, measurements of cortisol in amniotic fluid (which is mainly fetally derived) are often used as a proxy for fetal glucocorticoid exposure. Maternal cortisol and amniotic fluid cortisol concentrations are positively correlated [54, 58, 59].

In the postpartum period, maternal plasma cortisol levels fall and the function of the HPA axis gradually returns to its pre-pregnant state. Following delivery of the placenta, there is a sharp drop in placental CRH levels. The HPA axis is relatively hyporesponsive with lack of cortisol suppression to dexamethasone for up to 3 weeks postpartum [60] and dynamic tests showing recovery of CRH secretion by 12 weeks postpartum [61]. ACTH levels also fall transiently immediately after delivery, rising again 3-4 days postpartum [62]. Cortisol levels remain normal during the postpartum period due to elevated corticosteroid-binding globulin and the adrenal gland hypertrophy that occurred during pregnancy.

\section{Factors Influencing HPA Axis Activity during Pregnancy}

Longitudinal studies with repeated cortisol measurements suggest individual variability in cortisol levels is relatively stable across pregnancy $[63,64]$. So what are the pathways leading to interindividual variations in HPA axis activity in pregnancy? This has mostly been studied in the context of maternal 'stress' due to the documented association between a variety of different stressors ranging from chronic anxiety/depressive symptoms, to acute stressors such as bereavement or exposure to natural disasters, and poorer obstetric outcomes including reduction in gestational length, preterm delivery, and low birth weight (reviewed by Talge et al. [65]). Although many of these studies have not included measurements of maternal cortisol, it has been suggested that dysregulation of the HPA axis may underlie these associations. However, several studies show that stress and anxiety levels assessed by questionnaire do not necessarily correlate with maternal cortisol levels $[64,66]$. This may be related to limitations in the approaches used to assess stress and cortisol concentrations [67] as there is a higher correlation for ambulatory assessment of maternal stress and cortisol concentrations than single assessments carried out in a research laboratory [43]. Indeed there is some evidence that positive life events lower cortisol levels during pregnancy [68]. In contrast, a history of prior major stress (child abuse) increases the cortisol awakening response during pregnancy [69] whilst experience of chronic stressful life events during early pregnancy blunts peak salivary cortisol levels in the morning [70] suggesting different stressors have differing effects on HPA axis responses. Certain circumstances may increase a woman's vulnerability as exemplified by a recent study among US pregnant women of Mexican descent showing an association between increased 'acculturation', defined as members of one cultural group adapting to the beliefs and norms of another cultural group, and flatter diurnal slope of cortisol secretion in late pregnancy, the latter mediating the association between increased acculturation and lower birth weight [71]. Low socio-economic status is also associated with altered placental mRNA levels of genes important in glucocorticoid metabolism and action [72] and high maternal anxiety is associated with decreased placental HSD11B2 [51] and with higher levels of cortisol in amniotic fluid $[54,59]$. These studies suggest that even if circulating maternal cortisol levels do not change in association with maternal stressors, such stressors can still lead to increased glucocorticoid transfer to the fetus by the placenta.

Less well studied is whether the maternal HPA axis function alters in association with pathophysiological changes associated with pregnancy. There is some evidence of changes in cortisol levels [73] and of altered placental HSD11B2 expression [74] in association with preeclampsia, though whether these changes are cause or consequence of the disease is not clear. Whether the HPA axis changes in response to gestational hypertension, dia- 
Table 1. Maternal HPA axis and fetal growth

\begin{tabular}{|c|c|c|c|c|}
\hline Birth variable & $\begin{array}{l}\text { Cortisol } \\
\text { measurement }\end{array}$ & $\begin{array}{l}\text { Timing of } \\
\text { measurement }\end{array}$ & $\mathrm{n}$ & Findings \\
\hline \multicolumn{5}{|l|}{ Fetal growth } \\
\hline $\begin{array}{l}\text { Diego et al. } \\
2006[85]\end{array}$ & $\begin{array}{l}\text { Maternal urinary } \\
\text { cortisol }\end{array}$ & $\begin{array}{l}16-29 \text { weeks' } \\
\text { gestation }\end{array}$ & 98 & $\begin{array}{l}\text { Higher maternal urine cortisol associated with below average estimated fetal } \\
\text { weight measured by ultrasound OR } 12.8 \text { (95\% CI } 4.81-34.09)\end{array}$ \\
\hline $\begin{array}{l}\text { Li et al. } \\
2012[86]\end{array}$ & $\begin{array}{l}\text { Maternal blood } \\
\text { cortisol }\end{array}$ & Late gestation & 432 & $\begin{array}{l}\text { Maternal serum total cortisol was significantly negative correlated with } \\
\text { ultrasound parameters describing the fetal brain: late biparietal diameter } \\
\left(\mathrm{R}^{2}=0.512, \mathrm{p}=0.009\right) \text {, late head circumference }\left(\mathrm{R}^{2}=0.498, \mathrm{p}=0.001\right) \\
\text { middle biparietal diameter }\left(\mathrm{R}^{2}=0.819, \mathrm{p}=0.013\right) \text {, middle cerebellum } \\
\text { transverse diameter }\left(\mathrm{R}^{2}=0.76, \mathrm{p}=0.014\right) \text { and early biparietal diameter } \\
\left(\mathrm{R}^{2}=0.819, \mathrm{p}=0.013\right)\end{array}$ \\
\hline
\end{tabular}

Birth size

Goedhart et al.

2010 [87]

$\begin{array}{lll}\begin{array}{l}\text { Maternal serum } \\ \text { cortisol }\end{array} & \begin{array}{l}\text { Early second } \\ \text { trimester }\end{array} & 2,810\end{array}$

cortisol trimester

2,810 Higher cortisol associated with lower birth weight ( $\mathrm{B}=-0.35$ (95\% CI -0.53 , $-0.18), \mathrm{p}<0.001)$ and with small for gestational age $\mathrm{OR}=1.00(1.0-1.0)$, $\mathrm{p}=0.027$. However, findings no longer significant after adjustment for covariates (gestational age, infant gender, ethnicity, maternal age, parity, BMI, and smoking). Post hoc analysis revealed a moderation effect by time of day: only in those women who provided a blood sample $\leq$ 09:00 h ( $\mathrm{n}=94)$, higher maternal cortisol levels were independently related to lower birth weight $(\mathrm{B}=-0.94, \mathrm{p}=0.025)$ and a higher SGA risk $(\mathrm{OR}=1.01, \mathrm{p}=0.032)$

\begin{tabular}{|c|c|c|c|c|}
\hline $\begin{array}{l}\text { Bolten et al. } \\
2011[88]\end{array}$ & $\begin{array}{l}\text { Maternal salivary } \\
\text { cortisol awakening } \\
\text { response (CAR) }\end{array}$ & $\begin{array}{l}13-18 \text { (early) } \\
\text { and } 35-37 \text { (late) } \\
\text { weeks' gestation }\end{array}$ & 70 & $\begin{array}{l}\text { Lower birth weight associated with higher CAR in early }(\beta=-0.29, \mathrm{p}<0.05) \\
\text { and late }(\beta=-0.30, \mathrm{p}<0.01) \text { pregnancy, with overall CAR explaining } 19.8 \% \\
\text { of birth weight variance. Overall CAR also explained } 9 \% \text { of variance in birth } \\
\text { length }\end{array}$ \\
\hline $\begin{array}{l}\text { Hompes et al. } \\
2012[89]\end{array}$ & $\begin{array}{l}\text { Diurnal salivary } \\
\text { cortisol profile }\end{array}$ & Mid-pregnancy & 91 & $\begin{array}{l}\text { Basal cortisol predicted variance in birth weight (proportion of variance in } \\
\text { growth variable explained }(\mathrm{PVE})=11.6 \%) \text { and body mass index at birth } \\
(\mathrm{PVE}=6.8 \%)\end{array}$ \\
\hline $\begin{array}{l}\text { D’Anna-Hernandez } \\
\text { et al. } \\
2012[71]\end{array}$ & $\begin{array}{l}\text { Maternal diurnal } \\
\text { salivary cortisol } \\
\text { slope }\end{array}$ & $\begin{array}{l}15-18 \text { weeks } \\
\text { (early), 26-32 } \\
\text { weeks (mid) and } \\
>32 \text { weeks (late) } \\
\text { gestation }\end{array}$ & 55 & $\begin{array}{l}\text { Blunted maternal cortisol slope during late pregnancy associated with low } \\
\text { birth weight }(\mathrm{r}=-0.29, \mathrm{p}=0.05) \\
\text { No significant correlations in early or mid-pregnancy }\end{array}$ \\
\hline $\begin{array}{l}\text { Baibazarova et al. } \\
2012 \text { [59] }\end{array}$ & $\begin{array}{l}\text { Amniotic fluid } \\
\text { cortisol }\end{array}$ & Second trimester & 158 & $\begin{array}{l}\text { Higher amniotic fluid cortisol associated with lower birth weight }(r=-0.25 \text {, } \\
\mathrm{p}<0.01)\end{array}$ \\
\hline
\end{tabular}

betes or obesity has not been studied, though dietary manipulations in animal studies can alter maternal stress responses $[75,76]$, and specific dietary supplementation with the methyl donor choline in the third trimester alters the methylation profiles of genes in fetal derived tissues and in genes that regulate fetal glucocorticoid metabolism [77]. The above factors suggest that some fetuses will be more susceptible to changes in the maternal HPA axis than others, but there is also evidence that the fetus can itself respond to adverse conditions, for example signalling to the placenta to increase production of placental $\mathrm{CRH}$, allowing greater mobilisation of maternal glucose, when fetal metabolic demands increase [78]. Further work is needed to understand the cross-talk between fetus, placenta and mother and how this regulates glucocorticoid exposure to the fetus.

\section{Maternal HPA Axis and Offspring Outcomes}

In animal models ranging from studies in rodents to non-human primates, maternal treatment with glucocorticoids and manipulations that increase endogenous glucocorticoids or reduce HSD11B2 activity lowers offspring birth weight [79-81]. In some human studies the use of exogenous glucocorticoids administered to women at threat of preterm labour also lowers birth weight $[82,83]$. This does not hold true in all studies though which may reflect the importance of timing of steroid exposure [84]. There are now a number of studies showing that high endogenous cortisol levels in pregnant women, measured in blood, saliva, urine, or amniotic fluid negatively predict infant birth weight (table 1). The findings appear dependent on timing of sample collec- 
Table 2. Maternal HPA axis and gestation at delivery

\begin{tabular}{|c|c|c|c|c|}
\hline $\begin{array}{l}\text { Gestation at } \\
\text { delivery }\end{array}$ & $\begin{array}{l}\text { HPA axis } \\
\text { measurement }\end{array}$ & $\begin{array}{l}\text { Timing of } \\
\text { measurement }\end{array}$ & $\mathrm{n}$ & Finding \\
\hline $\begin{array}{l}\text { Hobel et al. } \\
1999[90]\end{array}$ & $\begin{array}{l}\text { Maternal plasma } \\
\text { cortisol, CRH and } \\
\text { ACTH }\end{array}$ & $\begin{array}{l}18-20,28-30 \\
\text { and } 35-36 \\
\text { weeks' } \\
\text { gestation }\end{array}$ & $\begin{array}{l}18 \text { pre-term and } \\
18 \text { controls }\end{array}$ & $\begin{array}{l}\text { Patients who had preterm delivery had significantly higher plasma } \\
\text { CRH levels }(\mathrm{p}<0.0001) \text { and ACTH levels }(\mathrm{p}<0.001) \text { than did control } \\
\text { subjects at all } 3 \text { gestational ages and significantly elevated cortisol } \\
\text { levels at } 18-20 \text { weeks' gestation and } 28-30 \text { weeks' gestation } \\
(\mathrm{p}<0.001)\end{array}$ \\
\hline $\begin{array}{l}\text { Mancuso et al. } \\
2004 \text { [91] }\end{array}$ & $\begin{array}{l}\text { Maternal plasma } \\
\mathrm{CRH}\end{array}$ & $\begin{array}{l}18-20 \text { and } 28-30 \\
\text { weeks' gestation }\end{array}$ & 282 & $\begin{array}{l}\text { Women who delivered preterm had significantly higher rates of CRH } \\
\text { at both } 18-20 \text { weeks' gestation and } 28-30 \text { weeks' gestation }(r=-0.37 \text {, } \\
\mathrm{p}<0.01 \text { and } \mathrm{r}=-0.41, \mathrm{p}<0.01 \text { respectively) compared with women } \\
\text { who delivered term }\end{array}$ \\
\hline $\begin{array}{l}\text { Sandman et al. } \\
2006[92]\end{array}$ & $\begin{array}{l}\text { Maternal plasma } \\
\text { cortisol and CRH }\end{array}$ & $\begin{array}{l}15,19,25 \text { and } 31 \\
\text { weeks' gestation }\end{array}$ & 203 & $\begin{array}{l}\text { CRH levels only at } 31 \text { weeks predicted preterm birth }(\mathrm{F} 1,201=5.53 \text {, } \\
\mathrm{p}=0.02) \text {; levels of cortisol were higher in women who delivered } \\
\text { preterm at } 15 \text { weeks' gestation }(\mathrm{F} 1,201=4.45, \mathrm{p}=0.03) \text { with a similar } \\
\text { trend at } 19 \text { weeks' gestation }\end{array}$ \\
\hline $\begin{array}{l}\text { Buss et al. } \\
2009 \text { [93] }\end{array}$ & $\begin{array}{l}\text { Maternal cortisol } \\
\text { awakening } \\
\text { response (CAR) }\end{array}$ & $\begin{array}{l}16.8(\mathrm{SD} 1.4) \\
\text { and } 31.4(1.3) \\
\text { weeks' gestation }\end{array}$ & 101 & $\begin{array}{l}\text { A larger CAR in late pregnancy and reduced attenuation of the CAR } \\
\text { from early to late gestation were associated significantly with shorter } \\
\text { gestational length } \\
\text { Less dampening of the CAR over the course of gestation by } \\
\text { approximately } 1 \% \text { per week are associated with reduction of } \\
\text { pregnancy duration by } 1 \text { week }\end{array}$ \\
\hline $\begin{array}{l}\text { Kramer et al. } \\
2009 \text { [94] }\end{array}$ & $\begin{array}{l}\text { Plasma CRH and } \\
\text { (in a subset) hair } \\
\text { cortisol }\end{array}$ & $\begin{array}{l}24-26 \text { weeks' } \\
\text { gestation }\end{array}$ & $\begin{array}{l}204 \text { preterm and } \\
444 \text { controls; } \\
\text { subset } \mathrm{n}=31 \\
\text { cases and } 86 \\
\text { controls }\end{array}$ & $\begin{array}{l}\text { Maternal plasma CRH was significantly higher in cases than in } \\
\text { control in crude analyses but not after adjustment (for concentrations } \\
\text { above the median, adjusted odds ratio }=1 / 1(95 \% \text { CI } 0.8-1.6)) \\
\text { In the subset, hair cortisol levels were positively associated with } \\
\text { gestational age. Concentrations were higher in the hair of women } \\
\text { who delivered at term than in those who delivered at }<34 \text { weeks' } \\
\text { gestation ( } 190.6 \text { SD } 99 \text { vs. } 148.6 \text { SD } 39.2 \mathrm{ng} / \mathrm{g}, \mathrm{p}<0.05)\end{array}$ \\
\hline $\begin{array}{l}\text { Entringer et al. } \\
2011[43]\end{array}$ & $\begin{array}{l}\text { Diurnal salivary } \\
\text { cortisol profile }\end{array}$ & $\begin{array}{l}23.4(\mathrm{SD} 9.1) \\
\text { weeks' gestation }\end{array}$ & 25 & $\begin{array}{l}\text { Higher salivary cortisol concentrations at awakening and throughout } \\
\text { the day }(\mathrm{p}=0.001) \text {, as well as a flatter cortisol response to awakening } \\
(\mathrm{p}=0.005) \text {, were associated with shorter length of gestation }\end{array}$ \\
\hline $\begin{array}{l}\text { Baibazarova } \\
\text { et al. } \\
2012[59]\end{array}$ & $\begin{array}{l}\text { Amniotic fluid } \\
\text { cortisol }\end{array}$ & Second trimester & 158 & $\begin{array}{l}\text { Higher amniotic fluid cortisol associated with shorter gestational age } \\
(\mathrm{r}=-0.18, \mathrm{p}<0.05)\end{array}$ \\
\hline
\end{tabular}

tion, gestation at assessment and whether total cortisol or free (bioavailable) cortisol is measured. Likewise, measurements of cortisol and CRH in blood, saliva, amniotic fluid and hair have been linked to altered length of gestation (table 2). The changes in cortisol are modest yet have major influences on outcome; for example a $2.6 \%$ increase in cortisol levels at awakening was associated with a 1-week shortening of pregnancy duration [43]. These findings suggest that high maternal cortisol levels can overcome the protective HSD11B2 barrier and pass across the placenta, slowing fetal growth and altering gestational length. In support of this concept, observational studies show that women who consume large amounts of liquorice which contains glycyrrhizin, an HSD11B2 inhibitor, during pregnancy have a shorter gestation [95]. Likewise, lower pla- cental HSD11B2 activity is correlated with lower birth weight $[96,97]$ and babies homozygous for deleterious mutations of the HSD11B2 gene are of lower birth weight, averaging $1.2 \mathrm{~kg}$ less than their heterozygote siblings [98]. Together these studies suggest increased exposure to cortisol is a critical factor regulating growth and gestation.

In addition to slowing fetal growth, excessive glucocorticoid exposure alters the set-point of the offspring HPA axis. Maternal and fetal/newborn cortisol levels are correlated $[50,99]$ and maternal cortisol levels are associated with reactivity of the newborn HPA axis as demonstrated in a recent study showing correlations between higher maternal cortisol levels in mid-late gestation and increased cortisol response in the newborn to the stress of a heel prick test [100]. The changes in offspring HPA 
axis activity associated with glucocorticoid overexposure in utero may persist into adult life as low birth weight is associated with higher fasting cortisol levels [101-103] and with activation of the HPA axis $[104,105]$. Likewise, increased cortisol reactivity has been demonstrated in 6to 11 -year-olds born at term who had prenatal glucocorticoid treatment [82].

Follow-up studies of infants exposed to antenatal glucocorticoids in utero suggest an increased risk of adverse neurodevelopmental outcomes. Though data are difficult to interpret as the babies are often born prematurely, studies have shown associations between antenatal glucocorticoid exposure and reduced head circumference at birth and an increase in distractibility and inattention in teenage offspring [106]. There is also some evidence that endogenous maternal HPA axis activity influences fetal neurodevelopment. For example, fetuses of mothers with higher CRH levels showed less habituation of the fetal heart rate to repeated vibroacoustic stimulation compared to those of mothers with low CRH levels [22]. This finding is thought to suggest impaired neurodevelopment as fetal heart rate habituation is known to correlate with later infant development at 18 months and 3 years of age [107]. There is inconsistency in the literature linking maternal cortisol to offspring temperament and emotional reactivity. Studies have shown higher maternal cortisol levels linked to offspring temperament, only cortisol measurements in the third trimester associating with infant emotional reactivity [20] or mental and motor development [108] while others have reported no associations between maternal cortisol measurements or amniotic fluid cortisol and these outcomes [59, 109].

Higher levels of amniotic cortisol have also been associated with lower cognitive scores in the infant at age 17 months [110]. Regulation of cortisol exposure through activity of HSD11B2 appears critical as the offspring of women who consumed large quantities of liquorice had significantly impaired cognitive and behavioural development $[111,112]$. A recent study has attempted to dissect the mechanisms underlying the altered infant neurodevelopment showing higher maternal cortisol levels measured in earlier but not later gestation were associated with a larger right amygdala volume measured by MRI in girls at age 7 years [113]. The amygdala is important for emotional memory processing and regulates a variety of emotions including fear, depression and anxiety. The higher maternal cortisol levels in early gestation were associated with more affective problems in girls, and this association was mediated in part by amygdala volume.

Maternal HPA Axis and Offspring

Outcomes
Intriguingly a prospective study of 6- to 9-year-olds also reported that pregnancy anxiety at 16 weeks, but not later in gestation, was associated with altered brain structure detected by MRI scans [114].

Exposure to exogenous glucocorticoids in utero is associated with adverse metabolic outcomes including higher blood pressure at age 14 years [21] and higher insulin levels at age 30 years [115]. Increased exposure to endogenous glucocorticoids, estimated from measurements of cord blood cortisol and cortisone, is also associated with higher blood pressure aged 3 years [116]. Maternal cortisol levels during pregnancy are also associated with changes in offspring body composition at 5 years, with higher maternal cortisol being independently associated with higher fat mass index in girls and lower fat mass index in boys, suggesting gender differences in offspring vulnerability [117].

Overall, these results support the hypothesis that overexposure to glucocorticoids increase the risk of development of both mental and physical illness in later life. Crucially, the timing of excess glucocorticoid exposure appears key to determining outcome suggesting there are critical windows of development during which different fetal organs and systems are vulnerable to glucocorticoids. For example, it is thought that cortisol early in pregnancy may prime the 'placental clock' predetermining the $\mathrm{CRH}$ surge and hence timing of delivery from very early in gestation [118]. Any insult occurring in early pregnancy may disrupt this exquisitely sensitive system. Other studies have shown different windows of susceptibility. For example, higher maternal cortisol in late pregnancy but not early pregnancy has been associated with more advanced physical and neuromuscular maturation in the neonate and mental development scores on the Bayley Scales at 12 months $[63,119]$ which is in keeping with the rapid development of the neural system which occurs between 28 and 32 weeks. Another potential explanation is that although the circulating levels of cortisol, ACTH and placental CRH rise as pregnancy progresses, the responsiveness of the HPA axis is blunted and this may protect mother and fetus to effects of stress in the later stages of pregnancy.

\section{Maternal Consequences of Stress and Altered HPA Axis Activity in Pregnancy}

Changes in maternal HPA axis activity influence timing of labour but are there any longer term consequences of dysregulation of the HPA axis during pregnancy for 
women? The observation that women who develop a physical illness in pregnancy such as pre-eclampsia are at later risk of hypertension and cardiovascular disease [120], suggests that pregnancy is itself a physiological stressor, and an adverse metabolic response to pregnancy predicts later disease susceptibility. Similarly, follow-up of women exposed to extreme stress in pregnancy indicate these women are at increased risk of adverse mental health [121]. In the non-pregnant state, activation of the HPA axis increases the risk of metabolic and psychiatric disease $[8,122-130]$. Preliminary evidence that altered HPA responses to pregnancy may influence later maternal mental health comes from a small study showing that increased cortisol responses to a standardized psychosocial stress test during healthy pregnancy predict postpartum depressive symptoms [131]. Further, higher midpregnancy CRH levels are associated with increased postpartum depressive symptoms [132]. In addition, dysregulation of the normal recuperation of the HPA axis in the postpartum period has been implicated in mood disorders occurring in that time period. For example, women who develop the postpartum 'blues' have been reported to have higher postpartum cortisol levels [133, 134], higher ACTH levels, a greater fall in CRH levels [62] and blunted responses to CRH testing [61]. In another study, patients with postpartum thoughts of harming the infant had higher levels of ACTH in the immediate postpartum period compared to women without these intrusive thoughts [135].

\section{Conclusions}

The challenges of measuring the dynamic and changing HPA axis in pregnancy have limited the translation of the numerous animal studies linking glucocorticoid overexposure to later disease into human studies. Nevertheless, evidence is accumulating showing changes in the maternal HPA axis leading to lower birth weight and gestation and long-term adverse health outcomes for the offspring. We currently do not know whether interventions during pregnancy to modulate HPA axis activity would be beneficial, though there is some evidence that use of simple stress reduction instructions can reduce maternal perceived stress as well as morning cortisol levels [136]. The early postpartum period may also be critical, as in animal studies postnatal care also effects offspring HPA axis function. Increased maternal care has been associated with enhanced negative feedback sensitivity of the axis, reduced CRH and reduced stress re- sponse, which consequently reduces fear behaviour in offspring [137, 138]. Cross-fostering studies with rats with high and low maternal care can reverse the phenotype of offspring [139]. These elegant studies suggest that a postnatal intervention may allow modification of some programmed changes. Therefore, early detection of, and preventative measures could have a huge impact on childhood neurodevelopment and adult mental health.

Given the difficulties in assessing the HPA axis in pregnancy, attention is turning to use of the placenta for biomarkers of future disease. One such biomarker is epigenetic markers, i.e. changes in gene expression such as DNA methylation, histone modification and chromatin packaging, which do not involve changes in DNA sequence. There is now preliminary evidence in humans that methylation levels of genes involved in glucocorticoid pathways are altered by the early life environment. Methylation of the HSD11B2 promoter is associated with reduced transcription [140] and a recent study has shown that increased DNA methylation of the HSD11B2 promoter in the placenta associates with lower birth weight and with altered newborn behaviour with poorer infant quality of movement, a marker of adverse neurobehavioural outcomes [141]. While these data are preliminary, they do suggest that it may be possible to identify at birth those most at risk of later disease.

\section{Acknowledgement}

We acknowledge the support of the British Heart Foundation and of Tommy's.

References

1 Barker DJ: The fetal origins of coronary heart disease. Acta Paediatr Suppl 1997;422: 78-82.

2 Barker DJP, et al: The relation of small head circumference and thinness at birth to death from cardiovascular disease in adult life. BMJ 1993;306:422-426.

3 Law CM, et al: Thinness at birth and glucose intolerance in 7-year-old children. Diabet Med 1995;12:24-29.

4 Hales CN, et al: Fetal and infant growth and impaired glucose tolerance at age 64. BMJ 1991;303:1019-1022.

5 Roseboom TJ, et al: Coronary heart disease after prenatal exposure to the Dutch famine, 1944-1945. Heart 2000;84:595-598.

-6 Ravelli ACJ, et al: Glucose tolerance in adults after prenatal exposure to famine. Lancet 1998;351:173-177. 
7 Stanner SA, et al: Does malnutrition in utero determine diabetes and coronary heart disease in adulthood? Results from the Leningrad siege study, a cross-sectional study. BMJ 1997;315:1342-1349.

8 Reynolds RM: Glucocorticoid excess and the developmental origins of disease: two decades of testing the hypothesis - 2012 Curt Richter Award Winner. Psychoneuroendocrinology 2013;38:1-11.

9 Seckl JR: Prenatal glucocorticoids and longterm programming. Eur J Endocrinol 2004; 151(suppl 3):U49-U62.

10 Nyirenda MJ, et al: Glucocorticoid exposure in late gestation permanently programs rat hepatic phosphoenolpyruvate carboxykinase and glucocorticoid receptor expression and causes glucose intolerance in adult offspring. J Clin Invest 1998;101:2174-2181.

11 Moss TJ, et al: Programming effects in sheep of prenatal growth restriction and glucocorticoid exposure. Am J Physiol Regul Integr Comp Physiol 2001;281:R960-R970.

$\checkmark 12$ McArthur S, et al: Perinatal glucocorticoid treatment disrupts the hypothalamo-lactotroph axis in adult female, but not male, rats. Endocrinology 2006;147:1904-1915.

$\checkmark 13$ Dodic M, et al: Programming effects of short prenatal exposure to dexamethasone in sheep. Hypertension 2002;40:729-734.

$\checkmark 14$ Dodic M, et al: An early prenatal exposure to excess glucocorticoid leads to hypertensive offspring in sheep. Clin Sci (Lond) 1998;94: 149-155.

15 Ortiz LA, et al: Prenatal dexamethasone programs hypertension and renal injury in the rat. Hypertension 2003;41:328-334.

- 16 De Blasio MJ, et al: Maternal exposure to dexamethasone or cortisol in early pregnancy differentially alters insulin secretion and glucose homeostasis in adult male sheep offspring. Am J Physiol 2007;293:75-82.

17 Kleinhaus K, et al: Effects of excessive glucocorticoid receptor stimulation during early gestation on psychomotor and social behavior in the rat. Dev Psychobiol 2010;52:121132.

$\checkmark 18$ Oliveira M, et al: Induction of a hyperanxious state by antenatal dexamethasone: a case for less detrimental natural corticosteroids. Biol Psychiatry 2006;59:844-852.

19 Hauser J, et al: Effects of prenatal dexamethasone treatment on physical growth, pituitaryadrenal hormones, and performance of motor, motivational, and cognitive tasks in juvenile and adolescent common marmoset monkeys. Endocrinology 2008;149:6343-6355.

20 Kelly BA, et al: Antenatal glucocorticoid exposure and long-term alterations in aortic function and glucose metabolism. Pediatrics 2012;129:1282-1290.

21 Doyle LW, et al: Antenatal corticosteroid therapy and blood pressure at 14 years of age in preterm children. Clin Sci 2000;98:137-142.

-22 Sandman CA, et al: Maternal corticotropinreleasing hormone and habituation in the human fetus. Dev Psychobiol 1999;34:163-173.
23 De Weerth C, van Hees Y, Buitelaar JK: Prenatal maternal cortisol levels and infant behavior during the first 5 months. Early Hum Dev 2003;74:139-151.

24 Rotmensch C, et al: The effect of antenatal steroid administration on the fetal response to vibroacoustic stimulation. Acta Obstet Gynecol Scand 1999;78:847-851.

25 Huttunen MO, et al: Prenatal loss of father and psychiatric disorders. Arch Gen Psychiatry 1978;35:429-431.

26 Imamura Y, et al: Life-time prevalence of schizophrenia among individuals prenatally exposed to atomic bomb radiation in Nagasaki. Acta Psychiatr Scand 1999;100:344349.

27 Izumoto Y, et al: Schizophrenia and the influenza epidemics of 1957 in Japan. Biol Psychiatry 1999;46:119-124.

28 Kinney DK, et al: Increased relative risk for schizophrenia and prenatal exposure to a severe tornado. Schizophr Res 1999;13:45-46.

29 Kunugi H, Nanko S, Takei N, Saito K, Hayashi N, Kazamatsuri H: Schizophrenia following in utero exposure to the 1957 influenza epidemics in Japan. Am J Psychiatry 1995; 152:450-452.

30 Yeragani VK, et al: The incidence of abnormal dexamethasone suppression in schizophrenia: a review and a meta-analysis comparison with the incidence in normal controls. Can J Psychiatry 1990;35:128-132.

31 Koenig JI, et al: Glucocorticoid hormones and early brain development in schizophrenia. Neuropsychopharmacology 2002;27:309318.

32 Clements $\mathrm{AD}$, et al: The incidence of attention deficit-hyperactivity disorder in children whose mothers experienced extreme psychological stress. Ga Educ Res 1992;91:1-14.

33 Van Os J, et al: Prenatal exposure to maternal stress and subsequent schizophrenia: the May 1940 invasion of The Netherlands. Br J Psychiatry 1998;172:324-326.

34 MacArthur BA, et al: School progress and cognitive development of 6-year-old children whose mothers were treated antenatally with betamethasone. Pediatrics 1982;70:99-105.

35 Jung C, et al: A longitudinal study of plasma and urinary cortisol in pregnancy and postpartum. J Clin Endocrinol Metab 2011;96: 1533-1540.

36 Qureshi AC, et al: The influence of the route of oestrogen administration on serum levels of cortisol-binding globulin and total cortisol. Clin Endocrinol 2007;66:632-635.

37 Demey-Ponsart E, et al: Serum CBG, free and total cortisol and circadian patterns of adrenal function in normal pregnancy. J Steroid Biochem 1982;16:165-169.

38 Hillhouse EW, et al: The identification of human myometrial corticotropin-releasing hormone receptor that increases in affinity during pregnancy. J Clin Endocrinol Metabol 1993;76:736-741.

39 Reis FM, et al: Putative role of placental corticotropin-releasing factor in the mechanism of human parturition. J Soc Gynecol Invest 1999;6:109-118.

40 Petraglia F, et al: Corticotropin-releasing factor-binding protein is produced by human placenta and intrauterine tissues. J Clin Endocrinol Metab 1993;77:919-924.

41 Robinson BG, et al: Glucocorticoid stimulates expression of corticotropin-releasing hormone gene in human placenta. Proc Natl Acad Sci USA 1988;85:5244-5248.

42 Mastorakos G, Ilias I: Maternal and fetal hypothalamic-pituitary-adrenal axes during pregnancy and postpartum. Ann NY Acad Sci 2003;997:136-149.

43 Entringer S, et al: Ecological momentary assessment of maternal cortisol profiles over a multiple-day period predicts the length of human gestation. Psychosom Med 2011;73:469474

44 De Weerth C, Buitelaar JK: Physiological stress reactivity in human pregnancy - a review. Neurosci Biobehav Rev 2005;29:295312

45 Kammerer M, et al: Pregnant women become insensitive to cold stress. BMC Pregnancy Childbirth 2002;2:8.

46 Wadhwa PD, et al: Placental CRH modulates maternal pituitary adrenal function in human pregnancy. Ann NY Acad Sci 1997;814:276281.

47 Benediktsson R, et al: Placental 11 $\beta$-hydroxysteroid dehydrogenase: a key regulator of fetal glucocorticoid exposure. Clin Endocrinol 1997;46:161-166.

$\checkmark 48$ Murphy BEP, et al: Conversion of maternal cortisol to cortisone during placental transfer to the human fetus. Am J Obstet Gynecol 1974; 118:538-541.

49 Lopez-Bernal A, et al: 11-Hydroxysteroid dehydrogenase activity (EC1.1.1.146) in human placenta and decidua. J Steroid Biochem 1980;13:1081-1087.

50 Gitau R, Fisk NM, Glover V: Human fetal and maternal corticotrophin-releasing hormone responses to acute stress. Arch Dis Child Fetal Neonatal Ed 2004;89:F29-F32.

51 O'Donnell KJ, et al: Maternal prenatal anxiety and downregulation of placental 11 $\beta$-HSD2. Psychoneuroendocrinology 2012;37:818-826.

52 Welberg LA, et al: Chronic maternal stress in hibits the capacity to up-regulate placental $11 \beta$-hydroxysteroid dehydrogenase type 2 activity. J Endocrinol 2005;186:R7-R12.

53 Mairesse J, et al: Maternal stress alters endocrine function of the feto-placental unit in rats. Am J Physiol Endocrinol Metab 2007; 292:1526-1533.

54 Glover V, et al: Association between maternal and amniotic fluid cortisol is moderated by maternal anxiety. Psychoneuroendocrinology 2009;34:430-435.

55 Ponder KL, et al: Maternal depression and anxiety are associated with altered gene expression in the human placenta without modification by antidepressant use: implications for fetal programming. Dev Psychobiol 2011; 53:711-723. 
56 Johnstone JF, et al: The effects of chorioamnionitisandbetamethasoneon $11 \beta$-hydroxysteroid dehydrogenase types 1 and 2 and the glucocorticoid receptor in preterm human placenta. J Soc Gynecol Investig 2005;12: 238-245.

57 Kossintseva I, et al: Proinflammatory cytokines inhibit human placental 11ß-hydroxysteroid dehydrogenase type 2 activity through $\mathrm{Ca}^{2+}$ and cAMP pathways. Am J Physiol Endocrinol Metab 2006;290:E282-E288.

58 Sarkar P, et al: Ontogeny of foetal exposure to maternal cortisol using mid-trimester amniotic fluid as a biomarker. Clin Endocrinol (Oxf) 2007;66:636-640.

59 Baibazarova E, et al: Influence of prenatal maternal stress, maternal plasma cortisol and cortisol in the amniotic fluid on birth outcomes and child temperament at 3 months. Psychoneuroendocrinology 2013; 38:907-915.

60 Owens PC, et al: Postnatal disappearance of the pregnancy-associated reduced sensitivity of plasma cortisol to feedback inhibition. Life Sci 1987;41:1745-1750.

61 Magiakou MA, et al: Hypothalamic corticotropin-releasing hormone suppression during the postpartum period: implications for the increase in psychiatric manifestations at this time. J Clin Endocrinol Metab 1996;81: 1912-1917.

62 O'Keane V, et al: Changes in the maternal hypothalamic-pituitary-adrenal axis during the early puerperium may be related to the postpartum 'blues'. J Neuroendocrinol 2011;23: 1149-1155.

63 Davis EP, Sandman CA: The timing of prenatal exposure to maternal cortisol and psychosocial stress is associated with human infant cognitive development. Child Dev 2010;81: 131-148.

-64 Voegtline KM, et al: Concurrent levels of maternal salivary cortisol are unrelated to selfreported psychological measures in low-risk pregnant women. Arch Womens Ment Health 2013;16:101-108.

-65 Talge NM, Neal C, Glover V: Antenatal maternal stress and long-term effects on child neurodevelopment: how and why? J Child Psychol Psychiatry 2007;48:245-261.

66 Harville EW, et al: Stress questionnaires and stress biomarkers during pregnancy. J Womens Health (Larchmt) 2009;18:1425-1433.

67 Wadhwa PD, et al: The contribution of maternal stress to preterm birth: issues and considerations. Clin Perinatol 2011;38:351-384.

68 Pluess M, et al: Positive life events predict salivary cortisol in pregnant women. Psychoneuroendocrinology 2012;37:1336-1340.

69 Bublitz MH, Stroud LR: Childhood sexual abuse is associated with cortisol awakening response over pregnancy: preliminary findings. Psychoneuroendocrinology 2012;37: 1425-1430.

70 Obel C, et al: Stress and salivary cortisol during pregnancy. Psychoneuroendocrinology 2005;30:647-656.
71 D’Anna-Hernandez KL, et al: Acculturation, maternal cortisol, and birth outcomes in women of Mexican descent. Psychosom Med 2012;74:296-304.

72 Raikkonen K, et al: Lower maternal socioeconomic position increase the placental glucocorticoid sensitivity and transfer. Eur J Psychotraumatol 2012;3(suppl 1):19554.

73 Vianna P, et al: Distress conditions during pregnancy may lead to pre-eclampsia by increasing cortisol levels and altering lymphocyte sensitivity to glucocorticoids. Med Hypotheses 2011;77:188-191.

74 Schoof E, et al: Decreased gene expression of $11 \beta$-hydroxysteroid dehydrogenase type 2 and 15-hydroxyprostaglandin dehydrogenase in human placenta of patients with preeclampsia. J Clin Endocrinol Metab 2001;86: 1313-1317.

75 Langley-Evans SC, et al: Protein intake in pregnancy, placental glucocorticoid metabolism and the programming of hypertension in the rat. Placenta 1996;17:169-172.

76 Gardner DS, Jackson AA, Langley-Evans SC: Maintenance of maternal diet-induced hypertension in the rat is dependent on glucocorticoids. Hypertension 1997;30:15251530.

77 Jiang X, et al: Maternal choline intake alters the epigenetic state of fetal cortisol-regulating genes in humans. FASEB J 2012;26:35633574 .

78 Herrmann TS, et al: Prolonged periods without food intake during pregnancy increase risk for elevated maternal corticotropin-releasing hormone concentrations. Am J Obstet Gynecol 2001;185:403-412.

79 Reinisch JM, et al: Prenatal exposure to prednisone in humans and animals retards intrauterine growth. Science 1978;202:436-438.

80 Novy MJ, Walsh SW: Dexamethasone and estradiol treatment in pregnant rhesus macaques: effects on gestation length, maternal plasma hormones and fetal growth. Am J Obstet Gynecol 1983;145:920-930.

-81 Mosier HD Jr, et al: Disproportionate growth of organs and body weight following glucocorticoid treatment of the rat fetus. Dev Pharmacol Ther 1982;4:89-105.

82 Alexander N, et al: Impact of antenatal synthetic glucocorticoid exposure on endocrine stress reactivity in term born children. J Clin Endocrinol Metab 2012;97:3538-3544.

83 Bloom SL, et al: Antenatal dexamethasone and decreased birth weight. Obstet Gynecol 2001;97:485-490.

84 Roberts D, Dalziel S: Antenatal corticosteroids for accelerating fetal lung maturation for women at risk of preterm birth. Cochrane Database Syst Rev 2006;3:CD004454.

85 Diego MA, et al: Maternal psychological distress, prenatal cortisol, and fetal weight. Psychosom Med 2006;68:747-753.

86 Li J, et al: Late gestational maternal serum cortisol is inversely associated with fetal brain growth. Neurosci Biobehav Rev 2012;36: 1085-1092.
87 Goedhart G, et al: Maternal cortisol and offspring birth weight: results from a large prospective cohort study. Psychoneuroendocrinology 2010;35:644-652.

88 Bolten MI, et al: Cortisol levels in pregnancy as a psychobiological predictor for birth weight. Arch Womens Ment Health 2011; 14:33-41.

89 Hompes T, et al: The influence of maternal cortisol and emotional state during pregnancy on fetal intrauterine growth. Pediatr Res 2012;72:305-315.

90 Hobel CJ, Arora CP, Korst LM: Corticotrophin-releasing hormone and CRH-binding protein. Differences between patients at risk for preterm birth and hypertension. Ann NY Acad Sci 1999;897:54-65.

91 Mancuso RA, et al: Maternal prenatal anxiety and corticotropin-releasing hormone associated with timing of delivery. Psychosom Med 2004;66:762-769.

-92 Sandman CA, et al: Elevated maternal cortisol early in pregnancy predicts third trimester levels of placental corticotropin-releasing hormone: priming the placental clock. Peptides 2006;27:1457-1463.

-93 Buss C, et al: The maternal cortisol awakening response in human pregnancy is associated with the length of gestation. Am J Obstet Gynecol 2009;201:398.e1-e8.

94 Kramer MS, et al: Stress pathways to spontaneous preterm birth: the role of stressors, psychological distress, and stress hormones. Am J Epidemiol 2009;169:1319-1326.

95 Strandberg TE, et al: Preterm birth and licorice consumption during pregnancy. Am J Epidemiol 2002;156:803-805.

96 McTernan CL, et al: Reduced placental $11 \beta$-hydroxysteroid dehydrogenase type 2 mRNA levels in human pregnancies complicated by intrauterine growth restriction: an analysis of possible mechanisms. J Clin Endocrinol Metab 2001;86:4979-4983.

$\$ 97$ Kajantie E, et al: Placental $11 \beta$-hydroxysteroid dehydrogenase-2 and fetal cortisol/ cortisone shuttle in small preterm infants. J Clin Endocrinol Metab 2003;88:493-500.

$\$ 98$ Dave-Sharma S, et al: Examination of genotype and phenotype relationships in $14 \mathrm{pa}-$ tients with apparent mineralocorticoid excess. J Clin Endocrinol Metab 1998;83:22442254.

99 Smith AK, et al: Predictors of neonatal hypothalamic-pituitary-adrenal axis activity at delivery. Clin Endocrinol (Oxf) 2011;75:9095.

100 Davis EP, et al: Prenatal maternal stress programs infant stress regulation. J Child Psychol Psychiatry 2011;52:119-129.

101 Phillips DI, et al: Elevated plasma cortisol concentrations: a link between low birth weight and the insulin resistance syndrome? J Clin Endocrinol Metab 1998;83:757-760.

102 Phillips DI, et al: Low birth weight predicts elevated plasma cortisol concentrations in adults from 3 populations. Hypertension 2000;35:1301-1306. 
103 Van Montfoort N, et al: Could cortisol explain the association between birth weight and cardiovascular disease in later life? A meta-analysis. Eur J Endocrinol 2005; 153: 811-817.

104 Reynolds RM, et al: Altered control of cortisol secretion in adult men with low birth weight and cardiovascular risk factors. J Clin Endocrinol Metab 2001;86:245-250.

105 Reynolds RM, et al: Is there a gender difference in the associations of birth weight and adult hypothalamic-pituitary-adrenal axis activity? Eur J Endocrinol 2005;152:249_ 253.

106 French NP, et al: Repeated antenatal corticosteroids: size at birth and subsequent development. Am J Obstet Gynecol 1999;180: 114-121.

107 Austin MP, Leader LR, Reilly N: Prenatal stress, the hypothalamic-pituitary-adrenal axis, and fetal and infant neurobehaviour. Early Hum Dev 2005;81:917-926.

108 Huizink AC, et al: Stress during pregnancy is associated with developmental outcome in infancy. J Child Psychol Psychiatry 2003;44: 810-818.

109 Gutteling BM, et al: The effects of prenatal stress on temperament and problem behavior of 27-month-old toddlers. Eur Child Adolesc Psychiatry 2005;14:41-51.

-110 Bergman K, et al: Maternal prenatal cortisol and infant cognitive development: moderation by infant-mother attachment. Biol Psychiatry 2010;67:1026-1032.

-111 Raikkonen K, et al: Maternal licorice consumption and detrimental cognitive and psychiatric outcomes in children. Am J Epidemiol 2009;170:1137-1146.

-112 Raikkonen K, et al: Maternal prenatal licorice consumption alters hypothalamic-pituitary-adrenocortical axis function in children. Psychoneuroendocrinology 2010;35: 1587-1593.

113 Buss C, et al: Maternal cortisol over the course of pregnancy and subsequent child amygdala and hippocampus volumes and affective problems. Proc Natl Acad Sci USA 2012;109:E1312-E1319.

114 Buss C, et al: High pregnancy anxiety during mid-gestation is associated with decreased gray matter density in 6- to 9 -year-old children. Psychoneuroendocrinology 2010;35: 141-153.

115 Dalziel SR, et al: Cardiovascular risk factors after antenatal exposure to betamethasone: 30 -year follow-up of a randomised controlled trial. Lancet 2005;365:1856-1862.
116 Huh SY, et al: Association between umbilical cord glucocorticoids and blood pressure at age 3 years. BMC Med 2008;6:25.

117 Van Dijk AE, et al: The relation of maternal job strain and cortisol levels during early pregnancy with body composition later in the 5-year-old child: the ABCD study. Early Hum Dev 2012;88:351-356.

118 Majzoub JA, et al: A central theory of preterm and term labor: putative role for corticotropin-releasing hormone. Am J Obstet Gynecol 1999;180:S232-S241.

119 Ellman LM, et al: Timing of fetal exposure to stress hormones: effects on newborn physical and neuromuscular maturation. Dev Psychobiol 2008;50:232-241.

120 Melchiorre K, et al: Preeclampsia is associated with persistent postpartum cardiovascular impairment. Hypertension 2011;58: 709-715.

121 Harville EW, et al: Combined effects of Hurricane Katrina and Hurricane Gustav on the mental health of mothers of small children. J Psychiatr Ment Health Nurs 2011;18:288296.

122 Albus M, Ackenheil M, Engel RR, Müller F: Situational reactivity of autonomic functions in schizophrenic patients. Psychiatry Res 1982;6:361-370.

123 Gallagher P, Watson S, Smith MS, Young $\mathrm{AH}$, Ferrier N: Plasma cortisol-dehydroepiandrosterone ratios in schizophrenia and bipolar disorder. Schizphr Res 2007;90:258265.

124 Gil-Ad I, Dickerman Z, Amdursky S, Laron Z: Diurnal rhythm of plasma $\beta$-endorphin, cortisol and growth hormone in schizophrenics as compared to control subjects. Psychopharmacology 1986;88:496-499.

125 Meewisse ML, Reitsma JB, de Vries GJ, Gersons BPR, Olff M: Cortisol and post-traumatic stress disorder in adults: systematic review and meta-analysis. Br J Psychiatry 2007;191:387-392.

126 Muck-Seler D, Pivac N, Jakovljevic M, Brzovic Z: Platelet serotonin, plasma cortisol, and dexamethasone suppression test in schizophrenic patients. Biol Psychiatry 1999;45:1433-1439.

127 Muck-Seler D, Pivac N, Mustapic M, Crncevic Z, Jakovljevic M, Sagud M: Platelet serotonin and plasma prolactin and cortisol in healthy, depressed and schizophrenic women. Psychiatry Res 2004;127:217-226.

128 Yilmaz N, Herken H, Cicek HK, Celik A, Yurekli M, Akyol O: Increased levels of nitric oxide, cortisol and adrenomedullin in patients with chronic schizophrenia. Med Princ Pract 2007;16:137-141.
29 Shirayama Y, Hashimoto K, Suzuki Y, Higuchi T: Correlation of plasma neurosteroid levels to the severity of negative symptoms in male patients with schizophrenia. Schizphr Res 2002;58:69-74.

130 Reynolds RM, Strachan MW, Braun A, Fowkes FG, Lee AJ, et al: Elevated fasting plasma cortisol is associated with ischemic heart disease and its risk factors in people with type 2 diabetes: the Edinburgh type 2 diabetes study. J Clin Endocrinol Metab 2010;95:1602-1608.

131 Nierop A, et al: Are stress-induced cortisol changes during pregnancy associated with postpartum depressive symptoms? Psychosom Med 2006;68:931-937.

132 Yim IS, et al: Risk of postpartum depressive symptoms with elevated corticotropin-releasing hormone in human pregnancy. Arch Gen Psychiatry 2009;66:162-169.

133 Okano T, Nomura J: Endocrine study of the maternity blues. Prog Neuropsychopharmacol Biol Psychiatry 1992;16:921-932.

134 Ehlert U, et al: Postpartum blues: salivary cortisol and psychological factors. J Psychosom Res 1990;34:319-325.

135 Labad J, et al: Increased morning adrenocorticotrophin hormone levels in women with postpartum thoughts of harming the infant. Psychoneuroendocrinology 2011;36: 924-928.

136 Urizar GG Jr, et al: Impact of stress reduction instructions on stress and cortisol levels during pregnancy. Biol Psychol 2004;67: 275-282.

137 Liu D, et al: Maternal care, hippocampal glucocorticoid receptors, and hypothalamic-pituitary-adrenal responses to stress. Science 1997;277:1659-1662.

138 Caldji C, et al: Maternal care during infancy regulates the development of neural systems mediating the expression of fearfulness in the rat. Proc Natl Acad Sci USA 1998;95: 5335-5340.

139 Francis D, et al: Nongenomic transmission across generations of maternal behavior and stress responses in the rat. Science 1999;286: $1155-1158$.

140 Alikhani-Koopaei R, et al: Epigenetic regulation of $11 \beta$-hydroxysteroid dehydrogenase type 2 expression. J Clin Invest 2004;114: 1146-1157.

141 MarsitCJ,etal:Placental 11 $\beta$-hydroxysteroid dehydrogenase methylation is associated with newborn growth and a measure of neurobehavioral outcome. PLoS One 2012;7: e33794. 